\title{
Trends in the Availability and Collection of Material for Family Research
}

\author{
By ELINA HAAVIO-MANNILA \\ University of Helsinki \\ Department of Sociology
}

The family researcher can make use of available material suitable for the solution of his research problem, or he can collect the data he needs himself. In the developed countries, demographic statistical material based on censuses and the recording of major life events (vital statistics) offers the easiest accessible information on some basic aspect of family life. The availability of demographic data varies, however, greatly in the different regions of the world. In the first part of this paper the availability of this material is examined at two points of time: in the 1950's and 1970's. The starting hypothesis was that the amount of statistical data to be used in family research has increased during the last 20 years. It was assumed that it is nowadays easier than in the 1950's to make cross-national comparative family studies on the basis of census data and vital statistics. The following pages shall show how well this hypothesis was supported by the data.

The second part of the paper discusses some relatively recent trends in the data gathering techniques in family research. It tries to show the increasing popularity of large scale surveys but also of case studies, historical studies and participant action research. Unlike the first section the second one is not based on statistical evidence. It relies on the personal impressions of the author who has mainly been following family research in Northern Europe. There is also one example of African family studies: two participant action researches conducted in Tanzania, in cooperation with Finnish researchers.

\section{Availability of demographic material for family research}

Between 1900 and 1972 almost 32000 books or articles were published on the research on marriage and the family (Aldous and Dahl 1974, XV). If we follow Aldous' and Dahl's classification we may say that demographic data offer material for family research mainly about mate selection, marriage and divorce, reproductive behavior, subcultural group membership and family, and family

* Paper originally presented at the 15th International Seminar on Family Research in Lomé, Togo, January 1976. 
Table 1. Availability of some natality, marriage, divorce, and population data in 1953 and 1973 .

Mid-year estimates of population in millions 2493 (1953), 3632 (1970)

$\begin{array}{lc}\begin{array}{c}\text { Proportion of the world population } \\ \text { for which data were available, percent }\end{array} \\ 1953 & 1962-731 \\ & \\ 55.2 & 42.4 \\ 54.0 & 92.9 \\ 32.9 & 41.6 \\ & \\ 38.7 & 38.9 \\ 36.8 & 41.5 \\ & \\ 24.6 & 37.7 \\ & \\ 29.5 & 33.5 \\ 29.3 & 33.7 \\ & \\ 46.1 & 38.5 \\ 25.0 & 37.7\end{array}$

Natality data

Number of live births

Crude live birth rates

Number of live births by age of mother

Marriage data

Crude marriage rates

Marriages

Marriages by age of bridegroom

and by age of bride

25.0

37.7

\section{Divorce data}

Divorces

Crude divorce rates

Population data

Population by marital status, sex and age

Size of household

(2)

Sources: Linder 1972:341, 351 and 353, and calculations based United Nations Demographic Yearbooks 1971 and 1973.

1 at least for one year between 1962 and 1973

life trends. Almost a quarter $(22,6 \%)$ of the family research publications in $1900-1972$ were related to these subject-matters.

But demographic material can also be usefully applied in macroscopic studies and in studies on research methodology (research aids) which formed 16,2 \% resp. $4,9 \%$ of the family litterature covered by the Aldous and Dahl bibliography. Family transactions with formal organizations, family as a small group, family and sex, families with special problems, and applied fields are probably subject-matters for which demographic data are not as suitable as for the firstmentioned topics.

The incomplete coverage of family-related characteristies presents serious problems for world-wide demographic and family research. Forrest E. Linder (1959, reprinted 1972) has made an interesting analysis of the contents of the United Nations Demographic Yearbook 1954. He calculated the proportion of the world population covered by various census and vital statistical data by 1953. For example, at that time there was published census information on marital status, age and sex for $46,1 \%$ of the world population (Forrester 1972, 341). ${ }^{1}$ According to my calculations based on the United Nations Demographic

1 Population by major eivil division had the highest coverage, $79,6 \%$, but data on population, urban and rural, by sex covered only $56,1 \%$ of the world population. 
Yearbooks similar statistics where in the 1970 's available for only $38.5 \%$ of the world population. Contrary to the starting hypothesis, coverage of the data had decreased rather than increased.

Table 1 shows that most types of family statistics are nowadays available to a somewhat greater degree than in the 1950's. But if we disregard the considerable increase in basic birth rate statistics, the increases are not large. Less than forty percent of the world population is covered by census data refering to family size or composition. And some of the vital statistics, like divorce rates, are not available for more than about a third of the world population.

Table 2. Availability of some natality, divorce, and population data by regions in 1953 and 1973.

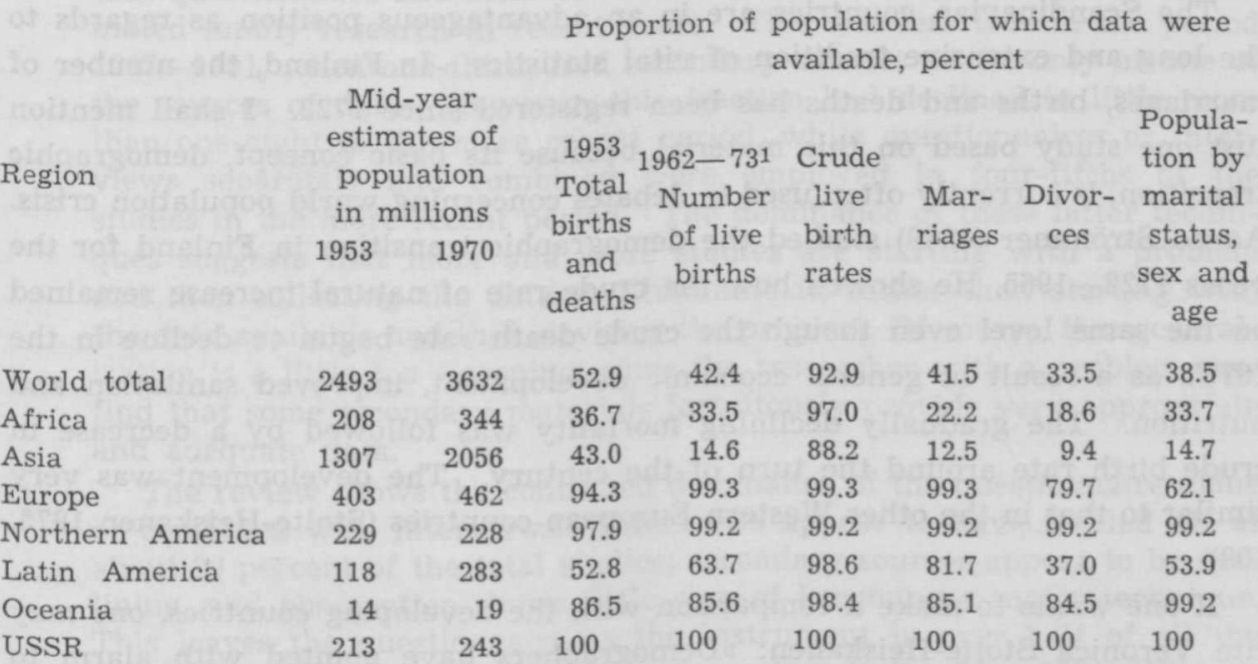

Sources: Linder 1972:346, and calculations based on United Nations Demographic Yearbooks 1971 and 1973

1 at least for one year between 1962 and 1973.

Table 2 shows that the coverage of the data is highest in the industrialized regions of the world: in Northern America, Europe and the Soviet Union. Also Oceania is relatively well covered. Latin-America offers somewhat more demographic information than Africa and Asia where the proportion of population for which demographic data are available, is very low. Due to lack of most data from China, Asia has the lowest coverage as regards to all family statistics.

The coverage of the United Nations Demographic Yearbooks is thus low if we are interested in more elaborated family data than crude birth rates. It is possible that the national statistical offices could provide more information than 
the published international sources. In a study on world alcohol production, commerce and consumption it was found that data were available for only 30 percent of the countries of the world when one looked at the international published statistics. But when a special survey - in order to increase the coverage of the data - was conducted (World Alcohol Project) official data were obtained from 54 percent of the countries (Bruun et al. 1975, 52). National data on demographic aspects of family life may thus be available even though they do not reach the United Nations publications.

In the developed countries there are already many underused statistical data on family life. For example, in Finland nuptiality has been relatively little studied even though there is plenty of material for instance on local homogamy and linguistic endogamy (deVries 1976). Fertility and mortality have been more frequently investigated, perhaps because of their "social problem» implications.

The Scandinavian countries are in an advantageous position as regards to the long and extensive tradition of vital statistics. In Finland, the number of marriages, births and deaths has been registered since 1722. I shall mention just one study based on this material because its basic concept, demographic transition, is currently often used in debates concerning world population crisis. Aarno Strömmer (1969) studied the demographic transition in Finland for the years 1722-1965. He showed how the crude rate of natural increase remained on the same level even though the crude death rate begun to decline in the 1870 's as a result of general economic development, improved sanitation and nutrition. The gradually declining mortality was followed by a decrease in crude birth rate around the turn of the century. The development was very similar to that in the other Western European countries (Stolte-Heiskanen 1975, 108).

If one wants to make a comparison with the developing countries, one may cite Veronica Stolte-Heiskanen: "Demographers have pointed with alarm to the significance of the model of 'demographic transition' for the population development of the Third World... The demographic situation in the Third World, however, differs significantly from the European historical pattern... Unlike in Europe, decreased mortality was not followed by a decrease in the birth rates. The present rate of growth of an average 2,5 per cent in the developing countries is almost twice as much as it has been in Europe at its most rapid growth stage. Demographers perceive this to be such an unprecedented situation that it demands a historically unique solution - namely, wide scale population control by the governments of the Third World.» $(1975,108-109)$ She continues by pointing out the continuing exploitation of the Third World by the same nations which press family planning programs upon it. It appears that there are only limited possibilities to solve the world population problem before the economical equity between the nations of the world increases.

Even though collecting of reliable demographic data as such does not help the developing countries avoiding exploitation, these data are valuable in 
planning and evaluating development in different social and economical areas. Insightful family research based on these data may help to clarify some features in the population dynamics.

\section{Collection of new material for family research}

Due to the poor availability of official demographic material in the world, and also because of its limited scope, the family researcher usually has or wants to collect his own empirical material himself. In Harold Christensen's »Handbook of Marriage and the Family» (1964) F. Ivan Nye analyzed data-gathering techniques in family research in the following way:

»The review of 456 studies published between 1947 and 1961 indicates that questionnaire and interview techniques of data-gathering have dominated family research in recent years. This was less true in the period 1947-1951, when one-third used secondary sources as the only or one of the sources of data. However, this fraction had declined to little more than one-eight in the more recent period, while questionnaires or interviews separately and combined were employed in four-fifths of the studies in the more recent period. The dominance of these latter techniques suggests that more and more studies are starting with a problem and then collecting the data to illuminate it, rather than starting with the data available and then devising the problem. Of course, this generalization is a little too sweeping, since the researcher with a problem may find that some secondary materials fortuitously provide very appropriate and adequate data.

The review shows the continued dominance of the questionnaire alone or combined with interviews. Interviews appear to have leveled off at about 20 percent of the total studies; secondary sources appear to be declining, and observation shows little sign of becoming a major technique. This leaves the questionnaire as the instrument in over half of all the published studies, with no other techique close to it.» (Nye 1964, 250).

Now, twelve years later it would be interesting to see a similar analysis of family research. One may suppose that questionnaires no longer have the same dominance they had in the 1950's. At least studies concerning college students' family life in which questionnaires were often used do no more interest publishers of research findings. Carlfred B. Broderick wrote in his Editorial for Journal of Marriage and the Family in May 1974 as an answer to the frequently asked question "why was my paper rejected?»: »The field has developed to the point today where no one cares what the sexual activities or marriage plans or whatever of the students in their courtship and marriage classes might be. A paper based on such a sample would only be considered if some other aspects of the study were unusually provocative or pioneering.» (Broderick 1974, 224).

In the following I try to present some observations on recent trends in family data collection techniques. They are based on personal, perhaps biased impressions about the development of the field. 
1) The importance of the case-study type of unstructured interview technique has increased since Oscar Lewis wrote his well-known family descriptions (1959, 1961 and 1968). As examples of this trend are studies by Sussman and Brooks (eds. 1973), Rapoport and Rapoport (1971 and 1975), Grønseth (1975), Haavio-Mannila (1975), Holter et. al. (1975), Sellerberg (1975) and Wiseman (1975). Except for some studies presented in Sussman and Brooks most of this research concerns European family life. In comparison to large surveys these studies cover only a limited number of respondents who have been selected according to certain criteria relevant to the research problem, often without following strict rules of statistical randomness. The families have been contacted several times, and often both spouses have been interviewed. These studies may reveal deeper aspects and problems in family life than large-scale surveys. The biases of interviewing only middle-class families or only wives (see Heiskanen 1971 and Safilios-Rothschild 1969) have to some degree been avoided.

2) Simultaniously with the growning importance of the smallscale microscopic family studies, at least in the Western industrialized countries (anthropological research has fulfilled the same function in the developing countries), my feeling is that also large-scale surveys based on personal interviews (not on questionnaires as in the 1950's) have increased due to better research resources in both capitalist and socialist industrialized countries. The family research seminar in Moscow 1972 showed a growing interest in empirical family research in the socialist countries where also the possibilities for statistical analysis of data are good due to well-developed automatic data processing systems.

In many countries, the survey has gained an appreciated status in the bureaucratic organization, too. For example, a study on sexual life and family size of Finns (Sievers, Koskelainen and Leppo 1974, Ritamies and Visuri 1975) was sponsored by the State Medical Board. The local public health nurses conducted the interviews achieving a response rate of $92,9 \%$ for a sample of more than 2000 interviewees. Even though the KAP (Knowledge, Attitudes, Practice) studies on fertility have been criticized for their methodological weaknesses and questionable results (Raulet 1970, Okediji 1973, and Stolte-Heiskanen 1973), their wide application in different parts of the world also shows the popularity of survey method in family (planning) research (Manual 1970, 189220). Another large-scale example of the use of survey method is the World Fertility Survey conducted in many countries. Data archives like the Interuniversity Consortium for Political Research also contain plenty of survey information on family matters; the material is available to any researcher.

3) An increasing interest in family history can be seen both among historians, sociologists and ethnologists. In some cases it is combined with the revival of the Marxist tradition in academic research, in some cases with the interest in the changing sex roles or family functions (Scott and Tilly 1975, Liljeström 1973), and in some cases with an increasing focus on social elements in ethnology 
(Löfgren 1972). The already classical works by Ariés (1962) and Laslett and Wall (1972) on the social history of the family have been followed by an energetic group of younger scholars. Some of its work was published in the special section of Journal of Marriage and the Family in August 1973, with Michael Gordon and Tamara Hareven as guest editors. "Journal of Family History: Studies in Family, Kinship, and Demography», began to be published by the National Council on Family Relations in the United States in 1976.

4) When Ivan F. Nye wrote his article on field research in family sociology there were no so-called participant action studies in which the researcher participates in the life of the research objects and tries to help them in strivings to improve their living conditions. As examples of participant family research I can mention two studies conducted at the University of Dar Es Salaam in Tanzania: "Youth and Development in the Coast Region of Tanzania» (Swantz 1974) and "Socio-Economic Causes of Malnutrition in Moshi District) (Swantz, Henricson and Zalla 1975). Marja-Liisa Swantz characterizes the requirements of development research in general in the following way:

1) Research conducted in a community should be planned so that part of it directly benefits that community. It should have a participantand action-oriented role in the community. For example, research on the water problem of an area could enlist the people's cooperation through conscious effort of solving their own problem, both in the thoughtprocess and the practical tests. Temporary solutions for the benefit of the people should be incorporated in the longterm scheme.

2) Research carried out for the benefit of a specific group of people should involve these people in some part of the research process wherever possible and practical. For instance a survey of potential skills in an area can become the people's own effort for evaluating their own potential resources.

3) Development research requires an interdisciplinary team approach. This in turn would lead to research planning in large units rather than in isolated piecemeal projects. When the problem arises from a practical need it requires practical solutions which in turn necessitates the cooperation of research workers from different fields. A problem arising from within the scientific context can be dealt within that same framework, but a problem arising in a practical situation is multidimensional.

4) Research involving people is by its very nature an educative process for all the categories of people engaged in the process. This aspect should be given recognition in research planning.» (Swantz 1975, 121)

In the child malnutrition study the method was based on observation:

"Students had participated in the life of the rehabilitation centre and been given instruction about malnutrition symptoms. In their observations and discussions with people they were guided by specific questions which were discussed at intervals with the supervisors. An extensive questionnaire was used, giving details of family histories, property, production and income, social relationships, educational background, as well as attitudes toward specific malnutrition incidences and also attendance in clinics. Only in exceptional cases, however, were the questionnaires used directly with the people. Instead they were filled in little by little through repeated visits to the same households and contacts with their neighbours 
and relatives. This meant that standardized efforts to approach all the people in the same manner were rejected, apart from getting answers to the same basic sets of questions from all. The information collected was based on as close acquaintance with the actual situation as was possible. This was facilitated by the fact that, with the exception of one, the students were working in their home areas and thus spoke the local language of the people.

The questions which proved difficult to get answers to concerned the size of fields, number of coffee trees, and income. Information given by relatives and the people themselves could differ. A rich man would undervalue his wealth and a poor man would quote higher figures. Another contrast sometimes was found between the information given by a husband and a wife. At times this was because of the wife's ignorance about household finances, at other times because of the wife's dissatisfaction with the care given by the husband to the family or the need for the husband to assure that it was not his neglect that was the cause of malnutrition. Neighbor's and relatives' views were compared with the views of the people themselves concerned. Thus through long-time exposure to the family situation by the observer and through cross-checking different sources, a degree of reliability could be achieved. (Swantz 1975, 125-126).

In participant research, a major aim is to motivate the people toward accomplishing the ultimate goal of the study. The concept of 'motivational tuning' (Himmelstrand and Okediji, 1968) was taken into consideration in designing the action research project on child malnutrition in Tanzania, the assumption being that motivation is significantly influenced by the mode of communication. Involving the people in the course of research means communicating ideas to the people, making them active transmitters and not terminal receivers (Swantz 1975, 128).

In this study family relationships - for example between different generations - and the position of men and women in the traditional Tanzanian village community were analyzed. The basic recommendations concerned economic development and improvement of food production. Activating women was one important goal of the research: "If women could see some hope in improving their economic and social position then perhaps they would be motivated to learn the basic facts of health also» (Swantz, Henricson and Zalla 1975, 76).

From the point of view of value free positivistic research ideology, participant action research is a strange phenomen. Swantz, however, points out that increased awareness of the people of the objectives of the research may well be an asset and may not necessarily result in biased data. She argues that the results are no more distorted if the control is maintained through close continued observation of the situation and rational involvement and participation of the people, than if they are left to guess at the real purposes and thus be directed by their own guesses rather than a rational thought process for their own benefit (Swantz 1975, 126).

Family research in the developing countries is not easy. For example, J. Ade. Alao (1974) has vividly described the difficulties involved especially when the research project is directed from outside the country. 


\section{Conclusion}

The scarcity of official, internationally published demographic data on marriage and the family presents serious obstacles for at least crosscultural family research. My somewhat arbitrary comparison on the coverage of some demographic variables in the 1950's and 1970's showed that the availability of the data has not substantially increased, except for crude birth rates.

These findings can perhaps be applied in the following ways:

Researchers can try to get the national governments to arrange more effectively the collection of basic demographic information through censuses and keeping record of life events. On the other hand, in some countries there may already be data gathered which never have become internationally known. Local researchers may have access to these data. They may analyze them and publish the results which then can be applied in furthering national development.

On the other hand, researchers can try to compensate for the lack of official statistics by conducting surveys, doing participant observation and action studies, making case studies of individual families or kin groups, and carrying out even historical studies - perhaps like ethnographers in Europe. The poor registration of people may make it difficult to draw proper random samples of the population. However, there are many other methods of selecting research objects.

\section{References}

Alao, J. Ade., The Survey Researcher in the Developing Countries: Prospects and Problems, in Marvin B. Sussman and Margaret B. Brooks (eds.), Family and the Bureaucratic Society, Department of Sociology, Case Western Reserve University, 1974 (stencil).

Aldous, Joan and Nancy Dahl, International Bibliography in Research in Marriage and the Family, Vol. II, 1965-1972, Ann Arbor, Michigan: The University of Minnesota Press, 1974.

Ariès, Philippe, Centuries of Childhood, A Social History of Family Life. Tr. by Robert Baldwick, New York: Knopf, 1962.

Broderick, Carlfred B., Editorial, Journal of Marriage and the Family, Vol. 36, No. 2, May 1974.

Bruun, Kettil et al., Alkoholipolitiikka, kansanterveydellinen näkökulma (Alcohol Politics, Public Health Perspective), Forssa: Alkoholitutkimussäätiön julkaisuja No. $26,1975$.

Grønseth, Erik, Worksharing families: Adaptations of pioneering families with husband and wife in part-time employment, Acta Sociologica, Journal of the Scandinavian Sociological Association, Vol. 18, No. 2-3, 1975.

Haavio-Mannila, Elina, Migration and Competence: Family-Organizational Linkages in Health and Welfare Life Sector, Research Reports, Institute of Sociology, University of Helsinki, No. 207, 1975. 
Heiskanen, Veronica Stolte, The Myth of the Middle-class Family in American Family Sociology, American Sociologist, 1971, 6 (1), 14-22.

Himmelstrand, Ulf and F. Olu. Okediji, Social Structure and Motivational Tuning in Social and Economic Development, Journal of Social Issues, Vol. 24, No. 2, 1968.

Holter, Harriet, Hildur Ve Henriksen, Arild Gjertsen and Haldis Hjort, Familien i klassesamfunnet, Oslo: Pax Forlag 1975.

Inter-university Consortium for Political Research, A Guide to Resources and Services 1973-1974, Ann Arbor, Michigan: Institute for Social Research, Center for Political Studies, The University of Michigan, 1974.

Journal of Marriage and the Family, Special Section: New Social History of the Family, ed. by Michael Gordon and Tamara Hareven, Vol. 35, No. 3, August 1973.

Laslett, Peter, Richard Wall (eds.), Household and Family in Past Time, Cambridge: Cambridge University Press 1972.

Lewis, Oscar, Five Families, New York: Basic Books, 1959.

Lewis, Oscar, The Children of Sanchez. Autobiography of a Mexican Family, New York: Vintage Books, 1961.

Lewis, Oscar, La Vida. A Puerto Rican Family in the Culture of Poverty, San Juan \& New York. London: A Panther Book, 1968.

Liljeström, Rita, Uppväxtvillkor, Stockholm: Almänna Förlaget 1973.

Linder, Forrest E., World Demographic Data, in Philip M. Hauser and Otis Dudley Duncan (eds.), The Study of Population, Chigago and London: The University of Chicago Press, 77 th impression 1972.

Löfgren, Orvar, Familj och hushåll - släkt och äktenskap, in Mats Hellspong och Orvar Löfgren, Land och stad, Lund: CWK Gleerup Bokförlag 1972.

A Manual for Surveys of Fertility and Family Planning: Knowledge, Attitudes, and Practice, New York: The Population Council, Demographic Division, 1970.

Nye, F. Ivan, Field Research, in Harold T. Christensen (ed.), Handbook of Marriage and the Family, Chicago: Rand Mc Nally \& Company, 1964, 247-274.

Okediji, F. O., Theoretical and Methodological Critique of Surveys of Knowledge, Attitudes and Practice in Family Planning in Africa, International Review of Modern Sociology, No. 3, 1973.

Rapoport, Rhona and Robert N. Rapoport, Dual-Career Families, Harmondsworth, Middlesex, England: Penguin Books 1971.

Rapoport, Rhona and Robert N. Rapoport, Leisure and the Family Life Cycle, London and Boston: Routledge \& Kegan Paul 1975.

Raulet, H. H., Family Planning and Population Control in Developing Countries, Demography, Vol. 7, No. 2, 1970.

Ritamies, Marketta and Elina Visuri, Suomalaisten perhekoko - sattuma vai suunnitelma (The Family Size of the Finns - Chance or Plan?), Helsinki: The Population Research Institute, D 1, 1975.

Safilios - Rotheshild, Constantina, Family Sociology or Wives' Family Sociology, Journal of Marriage and the Family, Vol. 31, No. 2, May 1969.

Scott, Joan. W. and Louise A. Tilly, Women's Work and the Family in Nineteenth-Century Europe, Comparative Studies in Society and History, Vol. 17, No. 1, January 1975.

Sellerberg, Ann-Mari, The Life of Young Working-Class Mothers in Sweden, Journal of Marriage and the Family, Vol. 37, No. 2, May 1975.

Sievers Kai, Osmo Koskelainen and Kimmo Leppo, Suomalaisten sukupuolielämä (The sexual life of the Finns), Porvoo: WSOY 1974.

Stolte-Heiskanen, Veronica, The Population Problem and Underdevelopment, Acta Sociologica, Journal of the Scandinavian Sociological Association, Vol. 18. No. 2-3, 1975. 
Strömmer, Aarno, The Demographic Transition in Finland, in Yearbook of Population Research in Finland XI, Helsinki: Population Research Institute, 1969.

Sussman Marvin B. and Margaret B. Brooks, Cross-National Family Research: Raport on Conceptual Development, Pilot Testing, Field and Administrative Issues, Cleveland, Ohio: Institute of the Family and the Bureaucratic Society, Department of Sociology, Case Western Reserve University, 1974 (stencil).

Swantz, Marja-Liisa, Youth and Development in the Coast Region of Tanzania, Bureau of Resource Assessment and Land Use Planning, University of Dar Es Salaam, Research Report No. 6, January 1974.

Swantz, Marja-Liisa, The Role of Participant Research in Development, Geografiska Annaler 57 B (1975) 2.

Swantz, Marja-Liisa, Ulla-Stina Henricson and Mary Zalla, Socio-Economic Causes of Malnutrition in Moshi District, Bureau of Resourse Assessment and Land Use Planning, The University of Dar Es Salaam, Research Paper No. 38, May 1975.

United Nations, Demographic Yearbook 1971 and 1973, New York 1972 and 1974.

Wiseman, Jacqueline P., An Alternative Role for the Wife of an Alcoholic in Finland, Journal of Marriage and the Family, Vol. 37, No. 1, February 1975.

de Vries, John, Local Homogamy and Linguistic Endogamy in Finland, 1951-1970, manuscript to be published in Acta Sociologica, Journal of the Scandinavian Sociological Association, 1976. 